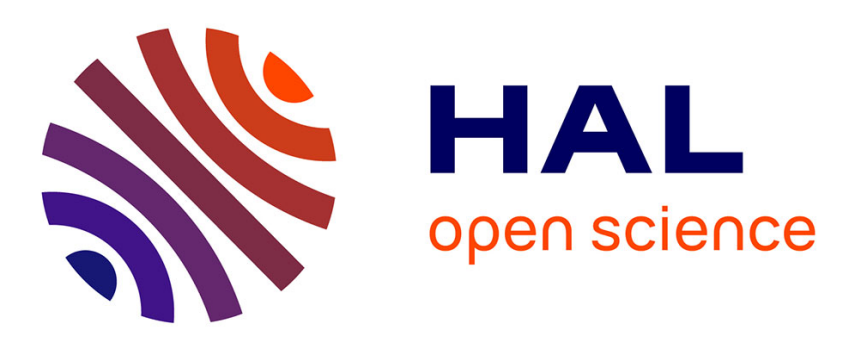

\title{
Insulin and (or) dexamethasone effectson leptin production and metabolic activitiesof ovine adipose tissue explants
}

Yannick Faulconnier, Carole Delavaud, Yves Chilliard

\section{- To cite this version:}

Yannick Faulconnier, Carole Delavaud, Yves Chilliard. Insulin and (or) dexamethasone effectson leptin production and metabolic activitiesof ovine adipose tissue explants. Reproduction Nutrition Development, 2003, 43 (3), pp.237-250. 10.1051/rnd:2003018 . hal-00900446

\section{HAL Id: hal-00900446 https://hal.science/hal-00900446}

Submitted on 1 Jan 2003

HAL is a multi-disciplinary open access archive for the deposit and dissemination of scientific research documents, whether they are published or not. The documents may come from teaching and research institutions in France or abroad, or from public or private research centers.
L'archive ouverte pluridisciplinaire HAL, est destinée au dépôt et à la diffusion de documents scientifiques de niveau recherche, publiés ou non, émanant des établissements d'enseignement et de recherche français ou étrangers, des laboratoires publics ou privés. 


\title{
Original article
}

\section{Insulin and (or) dexamethasone effects on leptin production and metabolic activities of ovine adipose tissue explants}

\author{
Yannick FAUlconNIER, Carole Delavaud, Yves ChILliarD* \\ Unité de Recherche sur les Herbivores, Équipe Tissu Adipeux et Lipides du Lait, \\ INRA-Theix, 63122 Saint-Genès Champanelle, France
}

(Received 22 July 2002; accepted 10 April 2003)

\begin{abstract}
The in vitro effects of insulin and/or dexamethasone (DEX) on leptin production were studied on adipose tissue (AT) from adult non-lactating, non-pregnant ewes. Perirenal AT explants were incubated for 2 or 4 days and leptin production was determined using a specific ovine RIA. The effects of these hormones were simultaneously measured on glucose and acetate utilisation and on lipogenic enzyme activities. A preliminary dose-response study showed a maximal leptin production by the addition in the incubation medium of $2 \mathrm{mIU} \cdot \mathrm{mL}^{-1}$ of insulin and $100 \mathrm{nM}$ of DEX. By using these concentrations, insulin or DEX increased leptin production by ovine AT explants whatever the incubation duration and the effects of these two hormones were additive. Insulin also increased substrate utilisation as well as lipogenic enzyme activities while DEX decreased substrate utilisation and did not change the lipogenic enzyme activities. To conclude, leptin response to DEX is specific and largely independent of the overall metabolic or lipogenic activity.
\end{abstract}

ewe / adipose tissue / leptin / insulin / dexamethasone

\section{INTRODUCTION}

Leptin, the product of the $o b$ gene, is a hormone secreted mainly by white adipocytes which is thought to communicate the status of adipose stores to central systems regulating food intake and energy expenditures. The expression of leptin by adipose tissue (AT) is highly correlated with body fatness in monogastric and ruminant species $[1,2]$. However, the factors potentially involved in this regulation have not been well identified. In rat or human AT, reports conflict on the respective effects of insulin and dexamethasone (DEX, a synthetic glucocorticoid) on leptin expression, and their interaction. Indeed, there are reports of either an inhibitory $[3,4]$ or a stimulatory $[5,6]$ effect of insulin

\footnotetext{
* Corresponding author: yves.chilliard@clermont.inra.fr
} 
on glucocorticoid-stimulated leptin mRNA and leptin production by rat or human AT. Furthermore, it was shown that insulin and glucocorticoid have depot-specific effects on leptin expression in human AT [7].

To our knowledge, there is only one study on the in vitro regulation of ruminant AT leptin expression by bovine subcutaneous AT explants in which insulin or DEX stimulated the leptin mRNA level [8]. In the ovine and bovine species, differences exist in the responses to insulin and/or DEX of AT explant lipogenic enzymes and substrate utilisation [9, 10]. Indeed, the effect of insulin on glucose and acetate utilisation is greater in bovine than in ovine AT whereas the contrary is true when DEX is added to the insulin-supplemented medium [9]. For the lipogenic enzyme activities, the effect of DEX in the presence of insulin is greater in ovine than in bovine AT [10]. Finally, the responses of leptin mRNA do not necessarily inform on the responses of leptin production or secretion by AT owing to the probable existence of post-translational regulation. Thus, the objectives of this study were to extend the knowledge to leptin production, to perirenal AT and to ovine species in order to better know and better understand the regulation of leptin expression in ruminants. We also assessed other AT responses by measuring the activity of three lipogenic enzymes, glucose-6-phosphate dehydrogenase (G6PDH, EC 1.1.1.49), malic enzyme (ME, EC 1.1.1.40) and lipoprotein lipase (LPL, EC 3.1.1.34), and the utilisation of two lipogenic substrates, glucose and acetate, in order to assess the specificity of the leptin response.

\section{MATERIALS AND METHODS}

\subsection{Animals and diets}

Adult (2-3-years-old) non-lactating nonpregnant ewes of the Lacaune breed $(n=8)$, weighing $64 \pm 6 \mathrm{~kg}$, were used. They were fed a restricted diet composed of straw $\left(400\right.$ to $500 \mathrm{~g} \cdot \mathrm{day}^{-1}$ ) for 7 days (that provided $20 \%$ of the maintenance energy requirements, MER) [11], and then they were overfed (200\% of the MER) for 13 days before slaughter, with ad libitum access to hay and water plus defined amounts of concentrate in order to maximise lipogenic enzyme activities prior to in vitro incubation. The composition and distribution of concentrate mix have been described previously [9]. Body condition was scored on a scale of 0 (very thin) to 5 (very fat). Before slaughter, the body condition averaged $3.5 \pm 0.2$ which showed that all the animals used in this study were in similar and good condition. The ewes were exsanguinated and after death, samples of perirenal AT were excised aseptically and immediately placed into an incubator vessel containing sterile Hanks buffer (Gibco / BRL, France), pH 7.4 at $37^{\circ} \mathrm{C}$.

All experimental procedures involving the use of animals were conducted according to the French recommendations for the use of experimental animals including animal welfare and appropriate conditions (Guidelines of 18 April 1998). In addition, all work involving the animals was carried out under the guidance of the Animal Care and Use Committee of INRA.

\subsection{Adipose tissue incubation}

The samples of perirenal AT were finely cut (10-15 $\mathrm{mg}$ pieces), transferred to plastic flasks and placed in an incubator at $37{ }^{\circ} \mathrm{C}$ with an atmosphere of $95 \% \mathrm{O}_{2}: 5 \% \mathrm{CO}_{2}$ (vol/vol). The AT explants (1-1.5 gram) were incubated in sterile Medium 199 (30 mL) containing Earles salts, L-glutamine and $25 \mathrm{mM}$ HEPES (pH 7.5; Gibco/BRL, France) supplemented with $7 \mathrm{mM}$ acetate (final concentration $7.6 \mathrm{mM}$ ), antibiotics and hormones as described previously [9, 12] and without serum [12]. The AT explants were incubated in duplicate for 2 or 4 days, and for each kind of medium: control without added hormones, insulin $(2,20$, 
$\left.100 \mathrm{mIU} \cdot \mathrm{mL}^{-1}\right), \operatorname{DEX}(10,100,1000 \mathrm{nM})$, and insulin plus DEX combinations. The reasons for using these hormone concentrations, and for then choosing $2 \mathrm{mIU} \cdot \mathrm{mL}^{-1}$ of insulin and $100 \mathrm{nM}$ of DEX are presented in Annexe 1 (Fig. 3). The incubation medium was replaced with fresh medium once every 48-h. Samples of each medium were retained after each 48-h incubation and stored at $-20{ }^{\circ} \mathrm{C}$ until glucose, acetate and leptin measurements. The enzyme activities were measured on AT explants after each incubation time ( 2 or 4 days).

\subsection{Adipose tissue measurements}

The preparation of the homogenates and the assay of tissue LPL activity were performed as described previously [12]. Briefly, tissue LPL activity was measured using an artificial emulsion containing ${ }^{3} \mathrm{H}$-triolein after a detergent (DeoxycholateNonidet P40, Sigma Chemical, SaintQuentin-Fallavier, France) extraction procedure. Enzyme activity was expressed in nmoles of released fatty acid $\cdot \mathrm{min}^{-1}$ per gram of tissue.

The G6PDH and ME activities were assayed spectrophotometrically as described previously [13]. Enzyme activities were expressed in nmoles of NADPH produced $\cdot \mathrm{min}^{-1}$ per gram of tissue.

\subsection{Incubation medium measurements}

The amounts of glucose and acetate removed from the incubation medium by AT explants was determined by measuring glucose and acetate concentrations at the beginning and the end of each 48-h incubation period for 4 days. The glucose and acetate concentrations were determined enzymatically using an ELAN auto-analyser (MerckClévenot S.A., Nogent-sur-Marne, France) [14]. Glucose concentration was analysed with the glucose dehydrogenase method using the Merck diagnostic kit (Nogent-sur-
Marne, France). Acetate concentration was analysed [15] using the Boehringer Mannheim kit (Meylan, France). Glucose and acetate utilisation were expressed in $\mu$ moles of glucose and acetate that was removed from the incubation medium $\cdot 48 \mathrm{~h}^{-1}$ per gram of tissue. The intraassay $\mathrm{CV}$ for acetate and glucose concentration and the $\mathrm{CV}$ of the incubation procedure were reported previously [12].

Leptin production in the incubation medium was determined in duplicate on $100 \mu \mathrm{L}$ aliquots using a disequilibrium, double-antibody, ovine-specific RIA [16]. Briefly, this assay utilised anti-ovine leptin rabbit antibody, recombinant ovine $\left[{ }^{125} \mathrm{I}\right]$ leptin, and recombinant ovine leptin as standard. The limit of sensitivity was $0.8 \mathrm{ng} \cdot \mathrm{mL}^{-1}$, and the within and between assay coefficients of variation were 6 and $9 \%$, respectively, with a lower limit of detection of $0.25 \mathrm{ng} \cdot \mathrm{mL}^{-1}$.

Before this homologous assay became available, leptin production in the incubation medium was also measured using a "multispecies" RIA supplied by Linco research (XL-85K, St Charles, MO). This analysis was performed according to a double-antibody method using guinea pig multispecies leptin antibody, human $\left[{ }^{125} \mathrm{I}\right]$ leptin, and human leptin as standard. As recommended by the manufacturer, the quantification was realised in $100 \mu \mathrm{L}$ of the incubation medium and all samples were tested in duplicate. The within- and between-assay variations were 9.0 and $15.1 \%$, respectively. Leptin production was expressed as ng. $48 \mathrm{~h}^{-1}$ per gram of tissue.

\subsection{Statistical analysis}

The data presented in Table I for the two incubation times were analysed using the GLM procedure of SAS (SAS Inst. Inc., Cary, NC). The statistical model included the effects of ewe, day of incubation (D), insulin (INS), dexamethasone (DEX) and the interactions between insulin and 
Y. Faulconnier et al.

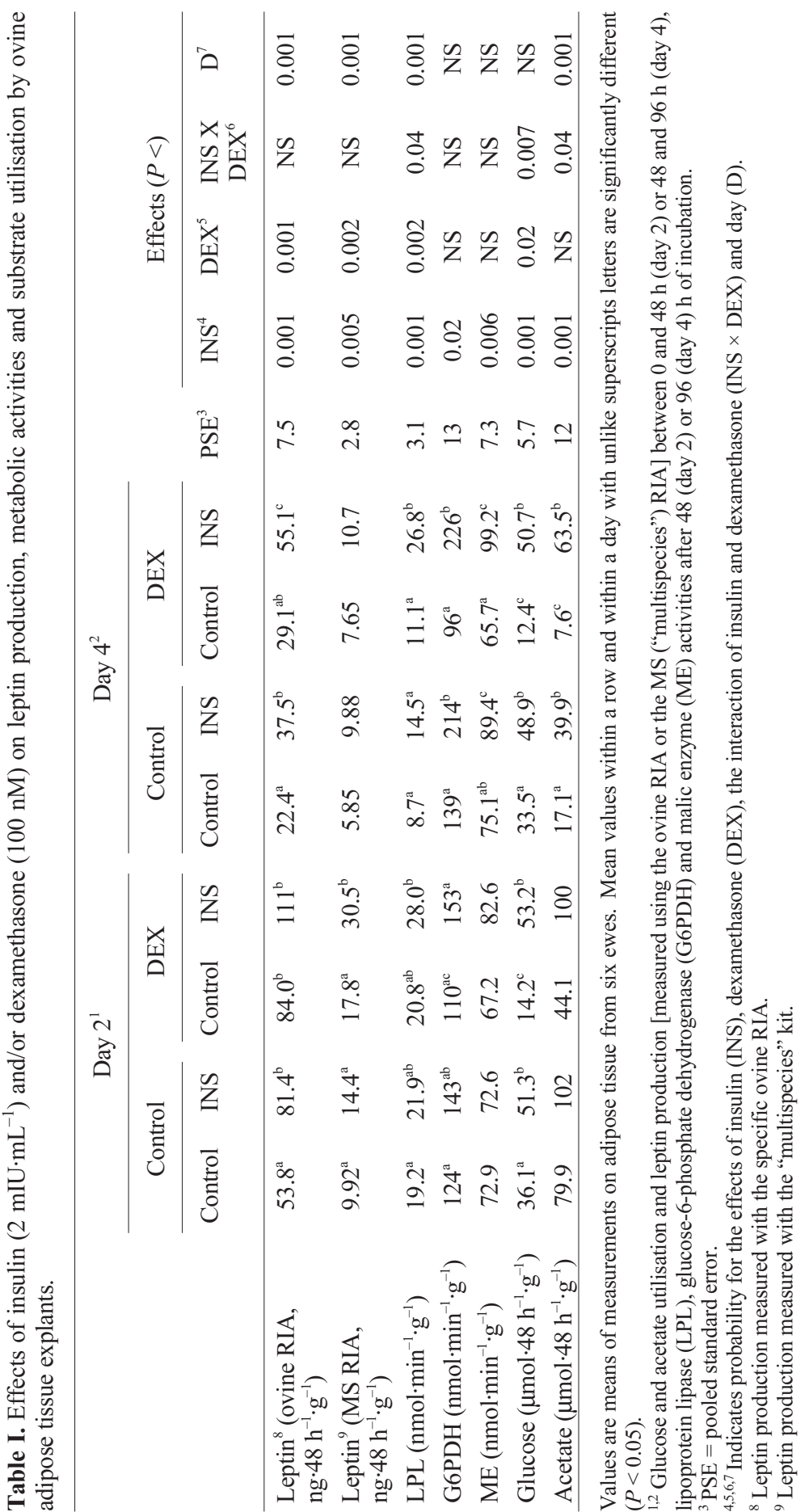


dexamethasone (INS $\times$ DEX), day and insulin $(\mathrm{D} \times \mathrm{INS})$, day and dexamethasone $(\mathrm{D} \times$ DEX) and day and insulin and dexamethasone $(\mathrm{D} \times \mathrm{INS} \times \mathrm{DEX})$. The residual error of the model was used as the error term for the various factors. The INS $\times \mathrm{D}$, the DEX $\times$ $\mathrm{D}$ and the INS $\times \mathrm{DEX} \times \mathrm{D}$ interactions were not significant $(P>0.10)$ and are not presented in the results.

The data presented in Table I were analysed for each incubation time with the GLM procedures of SAS (SAS Inst. Inc., Cary, NC) according to a statistical model accounting for the animal effect and comparing the four treatments (control, insulin, DEX, insulin and DEX). The differences between two treatments were tested using the Student-Newman-Keul-test with a probability of 0.05 .

\section{RESULTS}

\subsection{Leptin production in the incubation medium}

Whatever the hormone supplementation, leptin production measured with the specific ovine RIA was 2 to 3 fold higher $(P<0.001)$ during the first period of 48 -h incubation (day 1 and 2) than during the second period (day 3 and 4) (Tab. I). The addition of insulin alone or DEX alone in the medium significantly $(P<0.05)$ increased leptin production during day 1 and 2 ( +60 or $+58 \%$ for insulin or DEX, respectively, Fig. 1$)$ and during day 3 and $4(+67$ or $+30 \%$ for insulin or DEX, respectively, Tab. I). These effects were additive with a larger increase of leptin production in the presence of the two hormones [ $+118 \%$ during day 1 and 2 and $+146 \%$ during day 3 and $4(P<$ $0.05)$ when compared with control values] (Tab. I and Fig. 1).

The mean value of leptin production measured by the "multispecies" RIA $\left(15 \pm 11 \mathrm{ng} \cdot 48 \mathrm{~h}^{-1} \cdot \mathrm{g}^{-1}, n=56\right)$ was 4.5 times lower than that measured by the ovine RIA $\left(69 \pm 42 \mathrm{ng} \cdot 48 \mathrm{~h}^{-1} \cdot \mathrm{g}^{-1}\right)$. Despite this difference in absolute values, leptin productions measured using these two methods were strongly and linearly related $(r=0.84$; $n=56 ; P<0.001$; Fig. 2 ), due to similar relative responses to hormone additions. Indeed, insulin alone or DEX alone increased ( +45 or $+79 \%$, respectively) leptin production measured by the "multispecies" kit after 48-h of incubation (Tab. I). Moreover, leptin production on day 2 was greater $(+207 \%$ compared with control values, $P<0.05)$ in the presence of these two hormones (Tab. I).

\subsection{Substrate utilisation from the incubation medium}

Whatever the hormone supplementation, glucose utilisation was similar during day 1 and 2 and day 3 and 4 of incubation, whereas acetate utilisation was 2 to 6 fold higher $(P<0.001)$ during the first period than during the second period of 48-h incubation (Tab. I). The addition of insulin alone in the medium significantly $(P<0.05)$ increased glucose utilisation whatever the incubation period and acetate utilisation during day 3 and 4 . The addition of DEX alone in the medium significantly $(P<0.05)$ decreased glucose utilisation (day 1 to day 4) and acetate utilisation during day 3 and 4 . The inclusion of insulin prevented the inhibitory effect of DEX on glucose utilisation, and the addition of these two hormones in the incubation medium increased it $(+49 \%$, $P<0.05$ when compared with the control medium) with a positive interaction $(P<0.007)$ between these two hormones (Tab. I and Fig. 1). The addition of insulin and DEX in the medium had no significant effect on acetate utilisation during day 1 and 2 but increased it $(+271 \%, P<0.05$ when compared with the control values) during day 3 and 4, with a global positive interaction $(P<0.04)$ between these two hormones (Tab. I and Fig. 1). 

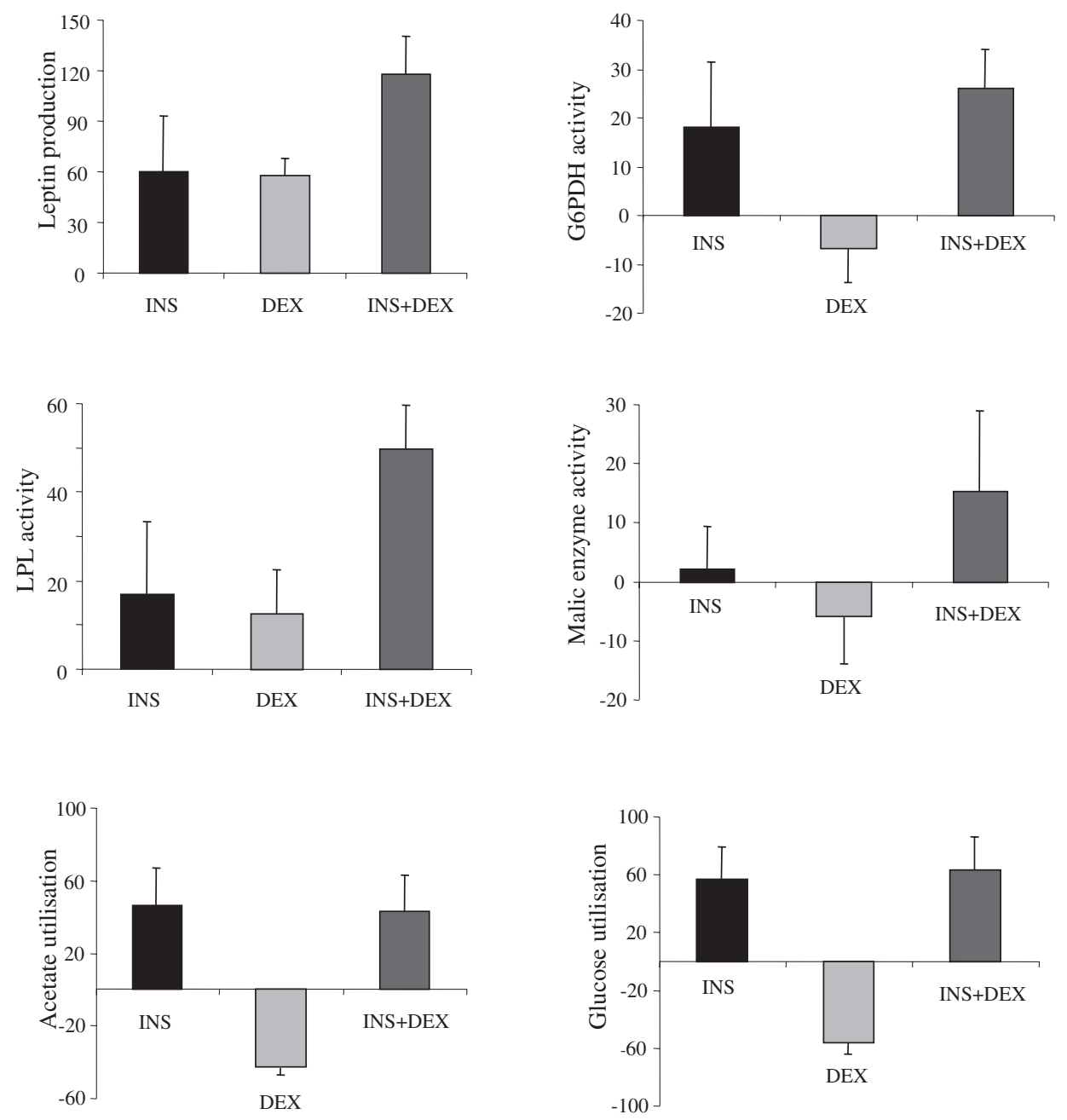

Figure 1. Response to insulin (INS, $2 \mathrm{mIU} \cdot \mathrm{mL}^{-1}$ ) and/or dexamethasone (DEX, $100 \mathrm{nM}$ ) addition ( $\%$ of control medium without added hormone) of leptin production (measured using ovine RIA), substrate utilisation and lipogenic enzyme activities of adipose tissue incubated for two days (mean \pm SEM, $n=6$ for each treatment). G6PDH = glucose-6-phosphate deshydrogenase, LPL = lipoprotein lipase.

\subsection{Lipogenic enzyme activities of adipose tissue explants}

Whatever the hormone supplementation, LPL activity was 1.5 fold higher $(P<0.001)$ after 2 days than after 4 days of incubation whereas G6PDH and ME activities remained stable (Tab. I). The addition of insulin in the medium significantly $(P<0.02)$ increased G6PDH and ME activities and more markedly on day 4 (Tab. I and Fig. 1). The addition of insulin or DEX in the medium significantly $(P<0.002)$ increased LPL activity with a significant $(P<0.04)$ positive 


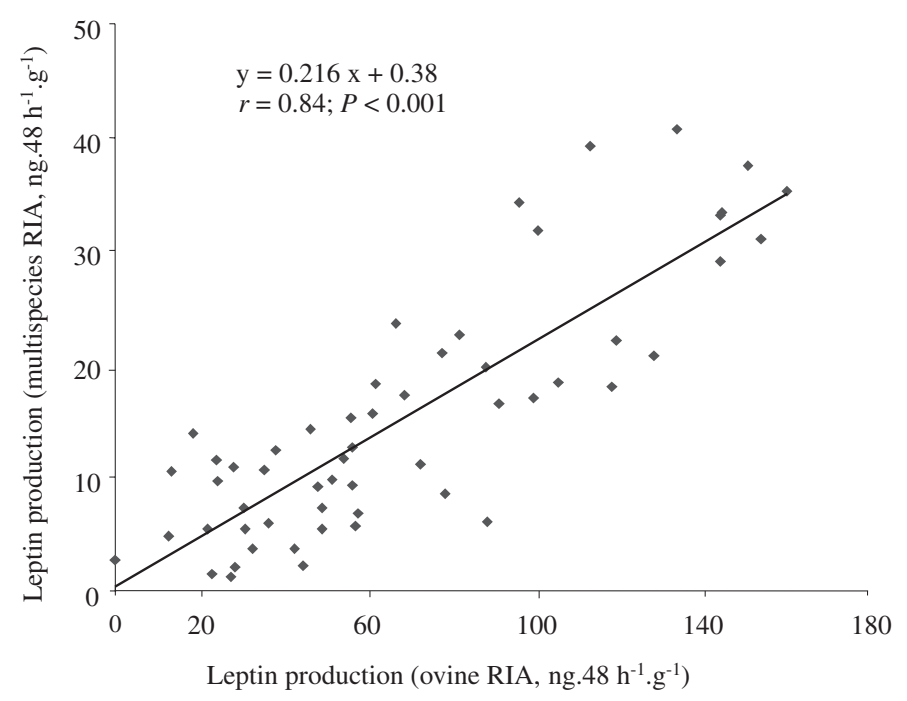

Figure 2. Relationship between leptin production determined by using either the ovine RIA or the "multispecies" RIA kit. The incubation medium $(n=56)$ was sampled after either 2 days ( 8 ewes) or 4 days (6 ewes) of incubation.

insulin $\times$ DEX interaction (Tab. I and Fig. 1). The addition of DEX in the medium did not affect G6PDH and ME activities (Tab. I) neither in the presence nor in the absence of insulin.

\subsection{Relationships between leptin production, lipogenic enzyme activities and substrate utilisation}

Within each hormonal treatment, leptin production was closely related to variations (between animals and day of incubation) of acetate utilisation or LPL activity (Tab. II), but not to those of glucose utilisation, G6PDH or ME activities (data not shown). The addition of insulin alone in the medium increased the slope and decreased the intercept of the acetate regression because this hormone more strongly increased the leptin production by tissues with high acetate utilisation. The addition of DEX alone in the medium increased the slope of the two regression equations (Tab. II) because DEX more strongly increased the leptin production by tissues with high acetate utilisation and/or LPL activity. However, the effect of DEX alone on the slope was more marked for acetate utilisation because DEX decreased it simultaneously to the increase in leptin production. The addition of insulin and DEX together increased the intercept of the regression between leptin production and LPL activity because it increased leptin production more than LPL activity whatever the LPL activity. The addition of insulin and DEX together increased the slope of the regression between leptin production and acetate utilisation because these hormones more strongly increased the leptin production by tissues with high acetate utilisation.

\section{DISCUSSION}

\subsection{Comparison between ovine RIA and the "multispecies" commercial kit}

The correlation observed for ovine AT leptin production in the medium between values determined by using either the ovine 
Y. Faulconnier et al.

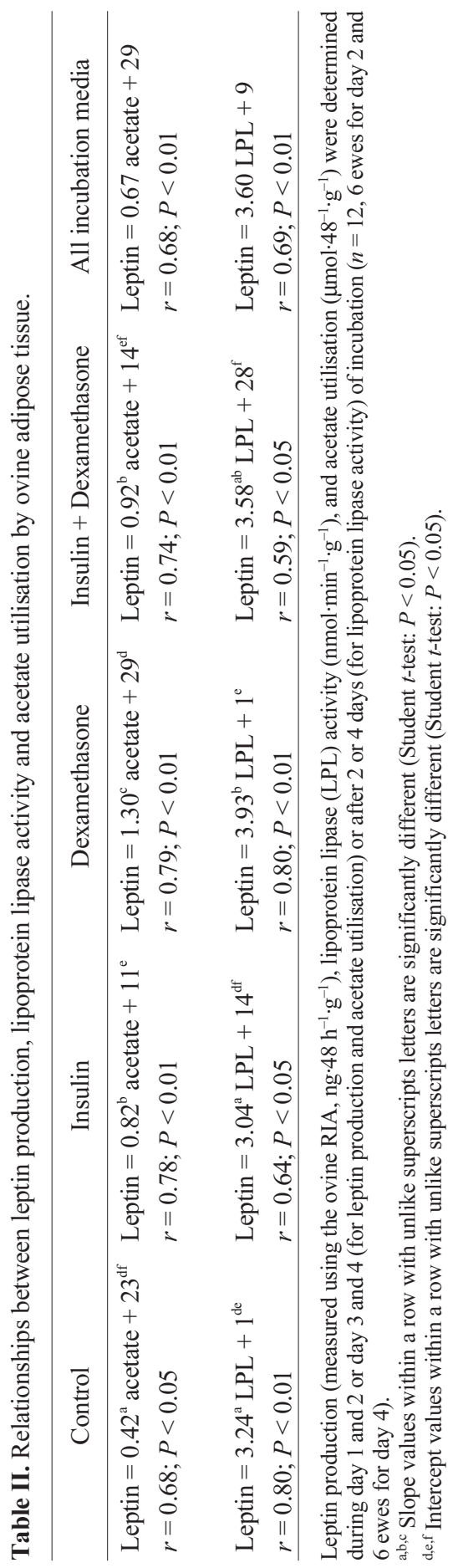


RIA or the "multispecies" commercial kit $(r=0.84)$ was high and similar to the correlation observed for ovine plasma samples $(r=0.87)$ [16]. Furthermore, the mean ratio between ovine RIA and the "multispecies" commercial kit was 4.5 in the present study and 3 to 4 in ovine or bovine plasma samples $[16,18]$, which could be due to insufficient sensitivity of the "multispecies" antibody. These similarities show that the relationship between the two methods is not changed by the presence or the absence of plasma proteins, including putative leptin binding proteins. Despite this limitation, quite similar relative effects of hormone addition were observed on leptin production when it was determined either by the ovine RIA or by the "multispecies" kit.

\subsection{Effect of insulin}

The addition of insulin alone in the medium increased leptin production from ovine AT explants (Tab. I and Fig. 1) in agreement with most of the in vitro studies on rat epididymal AT explants [19] and isolated adipocytes [5, 20, 21]. However in vitro data from human AT are much more controversial than those from rat AT (Tab. III). Indeed, insulin increased [6, 7, $22]$ or did not change $[3,7,23]$ leptin production according to the experimental conditions (tissue vs. adipocytes, incubation duration, hormonal concentrations used) but also to adipose depot site and gender.

The increase in leptin production from ovine AT after the addition of insulin could be partly explained by stimulation of leptin gene expression. Indeed, insulin significantly increases leptin mRNA levels in subcutaneous bovine AT explants incubated for $24 \mathrm{~h}$ [8]. In human subcutaneous AT, the responses of leptin mRNA level and leptin production are dependent on incubation duration: after 24 or $48 \mathrm{~h}$ of incubation, insulin has no effect $[3,22,23]$ while this hormone stimulates leptin mRNA level after $72 \mathrm{~h}$ of incubation and then increases leptin production in the medium after $96 \mathrm{~h}$ of incubation [22]. In isolated rat adipocytes, however,

Table III. Summary of the effects of insulin and/or dexamethasone on adipose tissue leptin expression in different species.

\begin{tabular}{|c|c|c|c|c|c|c|}
\hline \multirow{2}{*}{$\begin{array}{l}\text { Hormones } \\
\text { Leptin }\end{array}$} & \multicolumn{2}{|c|}{ INS vs. control ${ }^{\mathrm{a}}$} & \multicolumn{2}{|c|}{ DEX vs. control ${ }^{b}$} & \multicolumn{2}{|c|}{$\mathrm{INS}+\mathrm{DEX}$ vs. control ${ }^{\mathrm{c}}$} \\
\hline & mRNA & Production & mRNA & Production & mRNA & Production \\
\hline Human $^{i}$ & {$[\nearrow \text { or }=]^{\mathrm{d}}$} & {$[\nearrow \text { or }=]^{\mathrm{d}}$} & $\nearrow$ & {$[\nearrow \text { or }=]^{e}$} & $\nearrow^{\mathrm{f}}$ or $=\mathrm{g}$ & $\nearrow^{\mathrm{f}}$ or $=\mathrm{g}$ \\
\hline $\operatorname{Rat}^{\mathrm{j}}$ & $=$ & $\nearrow$ & $\nearrow$ & $\nearrow$ & $=\mathrm{g}$ & $\nearrow^{\mathrm{f}}$ \\
\hline Bovine $^{k}$ & {$[\nearrow \text { or }=]^{\mathrm{h}}$} & & {$[\nearrow \text { or }=]^{\mathrm{h}}$} & & $=g$ & \\
\hline Ovine $^{1}$ & & $\nearrow$ & & $\nearrow$ & & $\nearrow^{\mathrm{f}}$ \\
\hline
\end{tabular}

${ }^{\text {a }}$ Effect of insulin (INS) vs. control media.

${ }^{\mathrm{b}}$ Effect of dexamethasone (DEX) vs. control media.

${ }^{\mathrm{c}}$ Effect of insulin + dexamethasone (INS + DEX) vs. control media.

${ }^{\mathrm{d}}$ Dependent on incubation duration.

${ }^{\mathrm{e}}$ Dependent on the hormonal concentration used and on the incubation duration.

${ }^{\mathrm{f}}$ Additive effects between insulin and dexamethasone on leptin mRNA and/or production.

${ }^{g}$ Negative interaction between insulin and dexamethasone effects on leptin mRNA and/or production.

${ }^{\mathrm{h}}$ Dependent on the hormone concentration used.

${ }^{\mathrm{i}}$ Considine et al. [3], Fain et al. [24], Halleux et al. [23], Kolaczynski et al. [22], Russel et al. [7], Wabitsch et al. [6].

${ }^{j}$ Barr et al. [19], Bradley et Cheatham [20], Fain et Bahouth [26], Hardie et al. [5], Mueller et al. [21], Slieker et al. $[27]$.

${ }^{\mathrm{k}}$ Houseknecht et al. [8].

${ }^{1}$ Present study. 
insulin increases leptin production without affecting leptin mRNA level after $24 \mathrm{~h}$ of incubation [20].

The way insulin regulates leptin production by AT is not clear. In rat adipocytes, insulin increases leptin production by mobilising pre-existing intracellular pools of leptin, but de novo protein synthesis is required to obtain the full insulin effect [20]. In addition, it has been reported that insulin could act indirectly in rodents, by stimulating glucose transport and metabolism in adipocytes [21]. In human AT, the metabolism of glucose does not seem to be required to increase leptin production in abdominal adipose tissue explants [24] while in subcutaneous adipocytes, glucose metabolism to hexosamines is related to leptin production [17]. In our study on ovine AT, no relationship was observed between leptin production and glucose utilisation or G6PDH and ME activities, which are involved in glucose metabolism. This result agreed with the fact that, in vivo, glucose does not seem to be an important short-term ( $2 \mathrm{~h}$ ) regulator of plasma leptin levels in sheep [25], although a positive correlation between plasma glucose and leptin responses to meal intake ( $4 \mathrm{~h}$ after meal distribution) is observed in adult cattle [18]. Since we observed a strong correlation within each hormonal treatment between leptin production and acetate utilisation or LPL activity (Tab. II) and since insulin tended to increase acetate utilisation and LPL activity in ovine AT (Tab. I and Fig. 1), it is possible that insulin could act indirectly on leptin production in ruminants, by stimulating acetate or long-chain fatty acid utilisation by AT. Indeed, acetate and longchain fatty acids are major energy-yielding metabolites in ruminants.

\subsection{Effect of dexamethasone}

The increase in leptin production after the addition of DEX (Tab. I and Fig. 1) is in agreement with the fact that DEX increases the level of mRNA leptin in subcutaneous bovine AT explants incubated for $24 \mathrm{~h}$ [8]. All of the in vitro studies on rat and human AT also showed that DEX (1 to $1000 \mathrm{nM}$ ) addition increases (from 40 to $250 \%$ ) leptin production from isolated adipocytes $[3,5$, 26] or AT explants $[23,24,26]$ incubated for 24 or 48 h. Simultaneous changes in leptin production and leptin mRNA levels were shown after DEX addition in the medium with rat $[26,27]$ and human $[3,23]$ AT. This suggests a pretranslational regulation of the AT-leptin gene. Indeed, in rat adipocytes, the induction of the expression of the leptin gene by DEX is due at least in part, to an induction of the transcription of the leptin gene promoter [28].

Contrary to the positive effect observed on leptin production, the addition of DEX alone in the medium decreased glucose and acetate utilisation (Tab. I and Fig. 1) in agreement with the results observed previously in bovine and ovine AT explants [9]. However, this hormone did not significantly change G6PDH and ME activities. These different results show that the leptin response to DEX (contrary to insulin) is specific and partly independent of other effects of DEX on overall metabolic or lipogenic activity of AT.

\subsection{Additivity or interaction of insulin and dexamethasone effects}

The additivity between insulin and DEX effects on leptin production has not been reported previously in ruminant AT and suggests independent signalling routes for these effects. These results are consistent with those obtained from rat [5] and human [6] adipocytes incubated for $48 \mathrm{~h}$, with additive effects of insulin and glucocorticoid on leptin production. In contrast, other studies in human [3, 23], rat [20] and bovine [8] AT explants incubated for 24 or $48 \mathrm{~h}$ showed that the addition of insulin into the medium inhibited the stimulatory effect of DEX on leptin production or the mRNA level. The differences between our study and the 
bovine study could be related to differences between ruminant species and/or between AT sites. Indeed, in human AT [7], it was shown that insulin and glucocorticoid have depot-specific effects on leptin expression. Moreover, previous reports documented differences between ovine and bovine AT explants in lipogenic enzyme and substrate utilisation responses to insulin and/or DEX $[9,10]$. In contrast to the additivity between insulin and DEX effects on leptin production, a positive interaction between these two hormones was noted on substrate utilisation and LPL activity, in agreement with previous results on ovine AT, whereas only additive effects of these 2 hormones were observed on substrate utilisation and lipogenic AT activities in bovine AT $[9,10]$.

Further work is needed to unravel the mechanisms through which insulin and DEX modulate AT leptin mRNA and leptin production in different ruminant species, mechanisms which are likely to differ in part from those acting on overall metabolic or lipogenic activity. However, we observed (Tab. II) that the insulin and/or DEX effects were maximum in tissues which had the highest LPL activity and/or acetate utilisation.

The in vitro responses of AT leptin expression to insulin and/or DEX are quite similar between human, rat, bovine and ovine species (Tab. III). Furthermore, it appears that the responses of leptin mRNA to these hormones were less significant than the responses of leptin production, at least in the rat and ruminant species.

These in vitro results, combined with the in vivo effects of short to medium term changes in the nutritional state in ruminants, suggest that glucocorticoid-insulin-leptin interactions could play an important role in the dynamics of adaptation to underfeeding and refeeding in ruminants. Indeed, data in vivo showed that underfeeding decreased plasma leptin in cattle and sheep $[1,29]$ which in turn could contribute to increase cortisol [30,31] since leptin inhibits cortisol production [32] in bovine adrenocortical cells. This cortisol increase contributes to metabolic adaptations to undernutrition (protein mobilisation, gluconeogenesis, etc.) and stimulates refeeding behaviour $[1,33]$. Refeeding then stimulates insulin secretion, which in the presence of high cortisolemia stimulates leptin secretion, as shown in the present in vitro study. High leptinemia which inhibits both cortisol and insulin production [2], could then normalise cortisolemia and insulinemia, towards a new homeostatic equilibrium [1].

\section{CONCLUSION}

In conclusion, this study provides new data on the regulation of leptin production by ovine AT. Insulin or DEX increased leptin production to the same extent, whereas insulin increased, while DEX decreased or did not change the substrate utilisation, and the activity of lipogenic enzymes (Fig. 1). Thus the stimulatory effect of insulin on leptin release could be related to its metabolic effects, while the effect of DEX appears to be largely independent of its effect on adipose cell metabolism. Additional in vitro and in vivo studies on leptin expression are needed to better understand the mechanisms and the physiological significance of the effects of these hormones on leptin production.

\section{ACKNOWLEDGMENTS}

We thank Damien Chastrette, Jeannette Fléchet and Martine Tourret for technical assistance, as well as Alain Ollier and his team (Les Cèdres experimental unit) for animal management and R. Jailler for management of the slaughterhouse. 


\section{ANNEXE}

The effects of varying concentrations and combinations of insulin and/or dexamethasone on leptin production

The addition of 10,100 or $1000 \mathrm{nM}$ DEX alone in the incubation medium increased $(P<0.07$, i.e. when all 4 tissues responded positively) in a similar proportion (from 25 to $50 \%$ ) leptin production by ovine perirenal AT compared to control values (Fig. 3). In bovine subcutaneous AT incubated for $24 \mathrm{~h}$, Houseknecht et al. [8] observed no effect of $10 \mathrm{nM}$ DEX on the mRNA leptin level, whereas $100 \mathrm{nM}$ DEX stimulated it. Thus, it is possible that bovine subcutaneous AT had a lower sensitivity to DEX than ovine AT and/or that the response of leptin mRNA to DEX was less sensitive than leptin production. Moreover, a maximal stimulatory effect of DEX on leptin production was obtained at $50-100 \mathrm{nM}$ DEX in human AT explants [23], with a more marked effect in visceral than in subcutaneous AT [34], and at 100-1000 nM DEX in isolated rat adipocytes [27] incubated for 24 or $48 \mathrm{~h}$.

The addition of 2 or $20 \mathrm{mIU} \cdot \mathrm{mL}^{-1}$ insulin alone in the incubation medium increased $(P<0.07)$ leptin production by ovine perirenal AT $(+100$ and $+70 \%$, respectively) compared to control values, whereas the addition of the highest insulin concentration $\left(100 \mathrm{mIU} \cdot \mathrm{mL}^{-1}\right.$ ) had no effect (Fig. 3). In bovine subcutaneous AT incubated for $24 \mathrm{~h}$, Houseknecht et al. [8] reported a significant effect of 1.5 or $15 \mathrm{mIU} \cdot \mathrm{mL}^{-1}$ insulin on mRNA leptin level. With rat epididymal

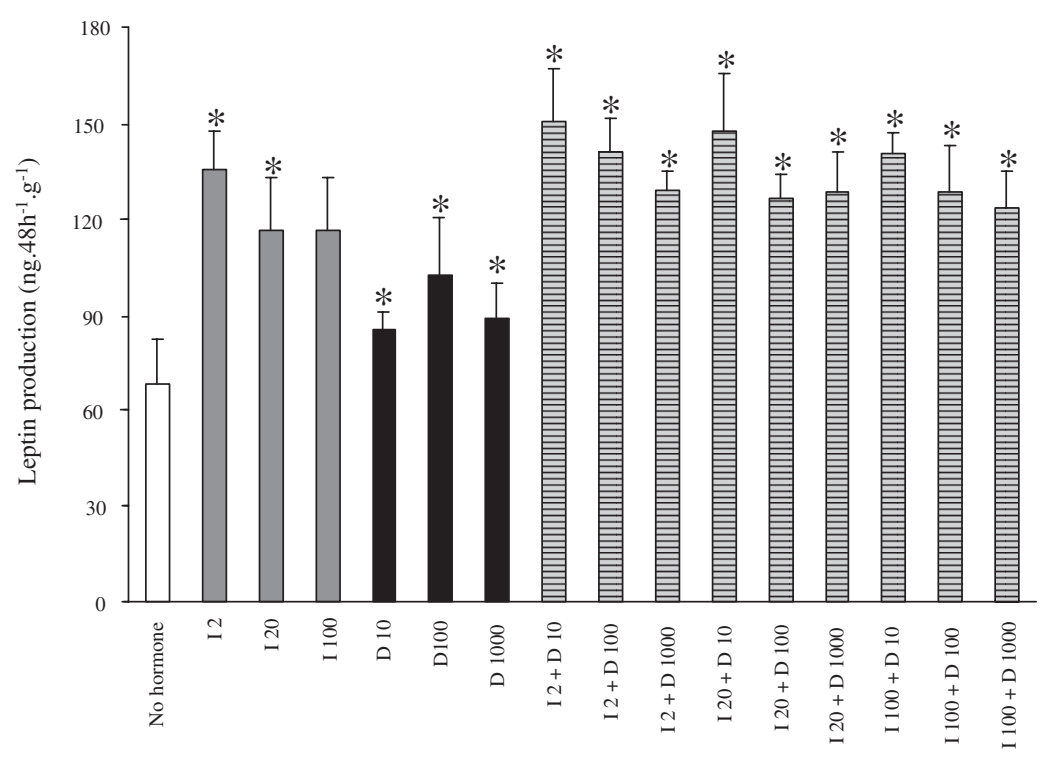

Hormones added

Figure 3. The effects of varying concentrations and combinations of insulin (I, expressed in $\mathrm{mIU} \cdot \mathrm{mL}^{-1} ; \mathrm{I} 2, \mathrm{I} 20, \mathrm{I} 100=2,20$ and $100 \mathrm{mIU} \cdot \mathrm{mL}^{-1}$ of insulin) and dexamethasone (D, expressed in $\mathrm{nM}$; D10, D100, D1000 $=10,100,1000 \mathrm{nM}$ of dexamethasone) on leptin production (measured using the ovine RIA) by ovine adipose tissue explants incubated for 2 days (mean \pm SEM, $n=4)$. ${ }^{*}$ Differences of leptin production between the control and media with added hormone: $P<0.07$ when all the four animals responded in the same direction (non parametric test for paired data, Wilcoxon $t$-test). 
adipocytes incubated for $48 \mathrm{~h}$, Hardie et al. [5] observed a dose-response of leptin production up to a plateau with 1.25 to $10 \mathrm{mIU} \cdot \mathrm{mL}^{-1}$ of insulin.

Whatever the insulin or DEX concentrations, the simultaneous addition of these two hormones into the medium increased $(P<0.07)$ leptin production $(+80-120 \%)$ above the control values. The highest increases (100-120\%) were observed in the presence of $2 \mathrm{mIU} \cdot \mathrm{mL}^{-1}$ and either 10 or $100 \mathrm{nM}$ of DEX.

In view of these results, we chose to work with $2 \mathrm{mIU} \cdot \mathrm{mL}^{-1}$ of insulin and $100 \mathrm{nM}$ of DEX, since these hormonal concentrations enabled maximal leptin yield responses to be achieved together with maximal stimulation of substrate utilisation and lipogenic activities during in vitro incubations of ruminant AT [12].

\section{REFERENCES}

[1] Chilliard Y, Bonnet M, Delavaud C, Faulconnier Y, Leroux C, Djiane J, Bocquier F. Review. Leptin in ruminants. Gene expression in adipose tissue and mammary gland, and regulation of plasma concentration. Domest Anim Endocrinol 2001, 21: 271-295.

[2] Houseknecht KL, Baile CA, Matteri RL, Spurlock ME. The biology of leptin: a review. J Anim Sci 1998, 76: 1405-1420.

[3] Considine RV, Nyce MR, Kolaczynski JW, Zhang PL, Ohannesian JP, Moore JH, Fox JW, Caro JF. Dexamethasone stimulates leptin release from human adipocytes: unexpected inhibition by insulin. J Cell Biochem 1997, 65: 254-258.

[4] Reul BA, Ongemba LN, Pottier AM, Henquin JC, Brichard SM. Insulin and insulin-like growth factor 1 antagonise the stimulation of $o b$ gene expression by dexamethasone in cultured rat adipose tissue. Biochem J 1997, 324: 605-610.

[5] Hardie LJ, Guilhot N, Trayhurn P. Regulation of leptin production in cultured mature white adipocytes. Horm Metab Res 1996, 28: 685-689.

[6] Wabitsch M, Jensen PB, Blum WF, Christoffersen CT, Englaro P, Heinze E, Rascher W, Teller W, Tornqvist H, Hauner H. Insulin and cortisol promote leptin production in cultured human fat cells. Diabetes 1996, 45: 1435-1438.
[7] Russel CD, Petersen RN, Rao SP, Ricci MR, Prasad A, Zhang Y, Brolin RE, Fried S. Leptin expression in adipose tissue from obese humans: depot-specific regulation by insulin and dexamethasone. Am J Physiol 1998, 275: E507-E515.

[8] Houseknecht KL, Portocarrero CP, Ji S, Lemenager R, Spurlock ME. Growth hormone regulates leptin gene expression in bovine adipose tissue: correlation with adipose IGF-1 expression. J Endocrinol 2000, 164: 51-57.

[9] Chilliard Y, Faulconnier Y. Insulin and (or) dexamethasone regulation of glucose and acetate utilization in ovine and bovine adipose tissue explants incubated for seven days. J Anim Sci 1995, 73: 2063-2070.

[10] Faulconnier Y, Guillon L, Chilliard Y. Lipoprotein lipase and glucose-6-phosphate dehydrogenase activities in bovine and ovine adipose tissue incubated for 7 days: effects of insulin and/or dexamethasone. Comp Biochem Physiol B 1996, 113: 421-426.

[11] INRA. Ruminant nutrition. In: Jarrige R (Ed). Recommended allowances and feed tables. John Libbey Eurotext, Paris. 1989.

[12] Faulconnier Y, Thévenet M, Fléchet J, Chilliard Y. Lipoprotein lipase and metabolic activities in incubated bovine adipose tissue explants: Effects of insulin, dexamethasone and fetal bovine serum. J Anim Sci 1994, 72: 184-191.

[13] Chilliard Y, Gagliostro G, Fléchet J, Lefaivre J, Sebastian I. Duodenal rapeseed oil infusion in early and midlactation cows. 5. Milk fatty acids and adipose tissue lipogenic activities. J Dairy Sci 1991, 74: 1844-1854.

[14] Ferlay A, Chilliard Y. Effects of the infusion of non-selective $\beta$-, and selective $\beta 1$ - or $\beta 2$-adrenergic agonists, on body fat mobilisation in underfed or overfed non-pregnant heifers. Reprod Nutr Dev 1999, 39: 409-421.

[15] Bergmeyer HU, Mollering H. In: Methods of Enzymatic Analysis. 2nd ed. Translated from the third German edition, Verlag chemie, Weinheim, 1974, p 1520.

[16] Delavaud C, Bocquier F, Chilliard Y, Keisler DH, Gertler A, Kann G. Plasma leptin determination in ruminants: effects of nutritional status and body fatness on plasma leptin concentration assessed by a specific RIA in sheep. J Endocrinol 2000, 165: 519-526.

[17] Considine RV, Cooksey RC, Williams LB, Fawcett RL, Zhang P, Ambrosius WT, Whitfield RM, Jones R, Inmam M, Huse J, McClain DA. Hexosamines regulate leptin production in human subcutaneous adipocytes. J Clin Edocrinol Metab 2000, 85: 3551-3556.

[18] Delavaud C, Ferlay A, Faulconnier Y, Bocquier F, Kann G, Chilliard Y. Plasma leptin 
concentration in adult cattle: effects of breed, adiposity, feeding level and meal intake. J Anim Sci 2002, 80: 1317-1328.

[19] Barr VA, Malide D, Zarnowski MJ, Taylor SI, Cushman SW. Insulin stimulates both leptin secretion and production by rat white adipose tissue. Endocrinology 1997, 138: 4463- 4472.

[20] Bradley RL, Cheatham B. Regulation of ob gene expression and leptin secretion by insulin and dexamethasone in rat adipocytes. Diabetes 1999 , 48: 272-278.

[21] Mueller WM, Gregoire FM, Stanhope KL, Mobbs CV, Mizuno TM, Warden CH, Stern JS, Havel PJ. Evidence that glucose metabolism regulates leptin secretion from cultured rat adipocytes. Endocrinology 1998, 139: 551-558.

[22] Kolaczynski JW, Nyce MR, Considine RV, Boden G, Nolan JJ, Henry R, Mudaliar SR, Olefsky J, Caro JF. Acute and chronic effect of insulin on leptin production in humans. Studies in vivo and in vitro. Diabetes 1996, 45: 699-701.

[23] Halleux CM, Servais I, Reul BA, Detry R, Brichar SM. Multihormonal control of $o b$ gene expression and leptin secretion from cultured human visceral adipose tissue: increased responsiveness to glucocorticoids in obesity. J Clin Endocrinol Metab 1998, 83: 902-910.

[24] Fain JN, Cowan GSM, Buffington C, Li J, Pouncey L, Bahouth SW. Synergism between insulin and low concentrations of isoproterenol in the stimulation of leptin release by cultured human adipose tissue. Metabolism 2000, 49: 804-809.

[25] Kauter K, Ball M, Kearney P, Tellam R, McFarlane JR. Adrenaline, insulin and glucagon do not have acute effects on plasma leptin levels in sheep: development and characterisation of an ovine leptin ELISA. J Endocrinol 2000, 166: 127-135.
[26] Fain JN, Bahouth SW. Stimulation of leptin release by actinomycin D in rat adipocytes. Biochem Pharmacol 1998, 55: 1309-1314.

[27] Slieker LJ, Sloop KW, Surface PL, Kriauciunas A, Laquier F, Manetta J, Bue-Valleskey J, Stephens TW. Regulation of expression of $o b$ mRNA and protein by glucocorticoids and cAMP. J Biol Chem 1996, 271: 5301-5304.

[28] De Vos P, Lefebvre AM, Shrivo I, Fruchart JC, Auwers J. Glucocorticoids induce the expression of the leptin gene through a non-classical mechanism of the transcriptional activation. Eur $\mathrm{J}$ Biochem 1998, 253: 619-626.

[29] Bocquier F, Bonnet M, Faulconnier Y, GuerreMillo M, Martin P, Chilliard Y, Effects of photoperiod and feeding level on perirenal adipose tissue metabolic activity and leptin synthesis in the ovariectomised ewe. Reprod Nutr Dev 1998, 38: 489-498.

[30] Chesworth JM, Easdon MP. Effect of diet and season on steroid hormones in the ruminant. J Steroid Biochem 1983, 19: 715-723.

[31] Homna KI, Homna S, Hiroshige T. Critical role of food amount for preffeeding corticosterone peak in rats. Am J Physiol 1983, 245: R339R344.

[32] Bornstein SR, Uhlmann K, Haidan A, EhrhartBornstein M, Scherbaum WA. Evidence for a novel peripheral action of leptin as a metabolic signal to the adrenal glands. Diabetes 1997, 46: 1235-1238.

[33] Strack AM, Sebastian RJ, Schwartz MW, Dallman MF. Glucocorticoids and insulin: reciprocal signals for energy balance. Am J Physiol 1995, 268: R142-R149.

[34] Fried SK, Russell CD, Grauso NL, Brolin RE. Lipoprotein lipase regulation by insulin and glucocorticoid in subcutaneous and omental adipose tissues of obese woman and men. J Clin Invest 1993, 92: 2191-2198. 